\title{
The Role of Corporate Governance on the Relationship Between IFRS Adoption and Earnings Management: Evidence From Bangladesh
}

\author{
Mohammad Tariq Hasan ${ }^{1,2}$ \& Azhar Abdul Rahman ${ }^{1}$ \\ ${ }^{1}$ School of Accountancy, College of Business, Universiti Utara Malaysia, Malaysia \\ ${ }^{2}$ SoBE, United International University, Dhaka, Bangladesh \\ Correspondence: Mohammad Tariq Hasan, PhD Student, School of Accountancy, College of Business, Universiti \\ Utara Malaysia and Assistant Professor, SoBE, United International University, Dhaka, Bangladesh. E-mail: \\ tariq2060@gmail.com
}

Received: March 27, 2020

Accepted: May 28, 2020

Online Published: July 7, 2020

doi:10.5430/ijfr.v11n4p329

URL: https://doi.org/10.5430/ijfr.v11n4p329

\begin{abstract}
Purpose: This study investigates the relationship between IFRS adoption and earnings management (EM) i.e. discretionary accruals (DA) and real earnings management (REM) in developing economy like Bangladesh. Moreover, the study examine the relationship between corporate governance (CG) strength and EM as well as moderating role of CG strength on the relationship between IFRS adoption and EM.

Design/methodology/approach: The study employs 94 firms listed in Dhaka Stock Exchange (DSE) for 6 years i.e. 564 firm years observation, over two time period as pre (2004-06) and post (2013/14-15/16) adoption of IFRS. Underpinning theory of the study is agency theory which explained the relationship among variables. Based on earlier literature a CG index is developed to measure the strength of CG. The study uses random effect GLS with robust regression in a balanced panel data.

Findings: The results show that IFRS and CGI both have significant negative relationship with EM. Moreover, it is documented that the CG strength significantly moderates the relationship between IFRS and REM. It implies that the presence of good CG may help to attain the objectives of IFRS adoption

Originality/value: To the best of the author's knowledge, this is one of the first empirical attempts at providing evidence about the role of CG on the relationship between IFRS adoption and EM in Bangladesh. The findings of this study can be beneficial for the member of the regulatory bodies and researchers to formulate new policy and enhance corporate governance practices in Bangladeshi companies as well as develop a better framework for all stakeholders involved in financial reporting. Future studies may also investigate the interacting effect of corporate governance strength on other related variables which may influence the level of earnings management.
\end{abstract}

Keywords: IFRS adoption, earnings management, corporate governance, discretionary accruals, real earnings management, Bangladesh

JEL Code: M40, M41, G34

\section{Introduction}

It has long been the craving of most international equity markets to have a standardized or unique set of guidelines for preparation of financial statements. Over the decades, every country has had its own national standards but it does not ensure information uniformity because of different set of standards. Accounting theory argues that the purpose of financial reporting is essentially to reduce information asymmetry between corporate managers and parties contracting with their firm (Ball, 2001) and financial reporting reduces information asymmetry by disclosing relevant and timely information (Frankel \& Li, 2004). IFRS is introduced as a single set of standard, to ensure the uniformity of accounting rules and regulation in practice. It may produce more reliable and simplified financial statements for the user. As a greater scope of comparability, managers are intended for less earnings management (Jeanjean \& Stolowy, 2008). Earnings management is considered as an imperative determinant of the quality of financial reporting (Dechow, Ge, \& Schrand, 2010; Key \& Kim, 2020). Explicitly, a diverse evidence is documented in various studies related to the outcome of IFRS adoption on financial reporting quality (Brüggemann, Hitz, \& Sellhorn, 2013; Kaaya, 2015). Several studies document that the quality of earnings is improved subsequent to the 
implementation of IFRS (Key \& Kim, 2020; Wong \& Wong, 2014). Liu, Yao, Hu, and Liu (2011) uncover that accounting information quality is enhanced significantly following the compulsory implementation of IFRS in China which is evaluated in view of lower level of EM. Similar results is identified by Chua, Cheong, and Gould (2012) in Australia and Wahyuni, Puspitasari, and Puspitasari (2020) in Indonesia. Subsequent to the implementation of IFRS in Malaysia, earnings quality of the listed firms is comparatively elevated than earlier period which is appraised in view of lower absolute value of abnormal accruals (Ismail, Kamarudin, Zijl, \& Dunstan, 2013). In contrast, alternative findings is also documented by the researchers where they provide evidence of no change of scenario or higher earnings manipulation (Wahyuningrum \& Rizqi, 2019; Yie Ke, 2020).

Earlier studies related to the effect of IFRS adoption on earning management, mainly focused on developed economy like EU countries, USA, Canada and Australia (Barth, Landsman, \& Lang, 2008; Chen, Tang, Jiang, \& Lin, 2010; Nijam \& Athambawa, 2016). The proponents of internationalization of IFRS may overlook the difference in economic and business characteristics between developed and developing countries. Even as IFRS adoption is practical for developed countries in terms of benefits, emergent economy may not be capable to accomplish similar advantages due to certain inherent limitation. This inherent limitation may be prevail in terms of weak governance, inefficient capital market, lack of knowledge and skill of the users, as well as different practices in culture (Judge, Li, \& Pinsker, 2010; Nijam \& Athambawa, 2016). Thus, it is necessary for the regulatory body to recognize the outcome of IFRS adoption on earnings management as well as compare it with the stated objectives of IFRS implementation, for better understanding of the accomplishment. (Barth et al., 2008). Previous studies on corporate governance and EM, mainly focused on the association among various corporate governance mechanisms and EM (Abdelkarim \& Zuriqi, 2020; El Diri, Lambrinoudakis, \& Alhadab, 2020; Hasan \& Rahman, 2019; Yasser, Mamun, Chapple, \& Chapple, 2016). This study focused on the firm's corporate governance strength which is measured by CG index following Brown and Caylor (2006); Salleh (2009).

In recent times, Bangladesh has moved to the lower middle earner group in view of Gross National Income per capita (GNI) according to World Bank ("World Bank Press Release," July 01, 2015). Earlier, Bangladesh is recognized as a prime nation among the Least Developed Countries (LDC's) where Bangladesh represents as an example to other LDC's, for the development and implementation of the international policy. It requires an intensive study to identify the effect of IFRS adoption in the developing economy. In addition Bangladesh capital market has suffered a market scam in 2009-10 which wipe out the investment and trust of the small investors. It may be the outcome of ineffective regulation and weak financial reporting framework (Hasan, Hossain, \& Rahman, 2014). Very few studies are conducted in respect of IFRS implementation procedures, its pros and cons as well as outcome of IFRS adoption in Bangladesh. Especially, the outcome of IFRS adoption on EM in Bangladeshi listed firms has not been studied so far. Thus, the study helps to comprehend the consequences of IFRS implementation on EM in developing economy like Bangladesh. The intent of the study can be identified in three parts: i) to examine the effect of IFRS adoption on EM in a developing economy, ii) to examine the affiliation between CG and EM, and iii) to explore the role of CG on the relationship between IFRS and EM.

\section{Literature Review and Hypothesis Development}

This study brings into light various issues related to International Financial Reporting Standard (IFRS), Earnings Management (EM) in terms of accruals management and real earnings management, Corporate Governance (CG), with the concentration on the effect of IFRS adoption on EM. Agency theory explain the theoretical background of the issue linked to the separation of ownership and management. Designing and implementation of accounting standard is an important aspect to improve decision making capacity of the investors and it also serves as an effective tool for managers performance evaluation (Scott, 2014). Financial reporting procedures provide information about management stewardship of resources which is required by the investors or other stakeholders for evaluation. Conflicting issue between management and users of financial reporting is explained through agency theory (Jensen $\&$ Meckling, 1976). This study is structured under the framework of agency theory which highlights the issue of agency conflict i.e. the relationship between management and owners as well as positive accounting theory (efficient contracting perspective and opportunistic perspective) where theory explains that managers are rational and choose accounting practices for their best interest (i.e. opportunistic), if possible (Scott, 2014). As it is not always possible for the firm to ensure efficient contracts over time. Moreover, managers judgment is often required for the preparation of the financial statement (Fama, 1980). In this aspect, accounting standards have been anticipated to reduce the opportunistic managerial behavior and reduce the of information asymmetry (Iatridis, 2010). The global movement for the adoption of IFRS as a single set of standard with its higher disclosure requirements to ensure transparency may tend to reduce managerial discretion and consequently EM (Byard, Li, \& Yu, 2011; Wahyuni et al., 2020). 


\subsection{IFRS Adoption and Earnings Management}

The implementation of IFRS may offer higher accounting quality by ensuring comparability and transparency of the financial statements which reduce the magnitude of earnings manipulation (Gordon, Jorgensen, \& Linthicum, 2011; Hasan \& Rahman, 2017; Kaaya, 2015; Nouri \& Abaoub, 2014). Cai, Rahman, and Courtenay (2008) documented significant reduction of earnings management subsequent to the implementation of IFRS in different countries. The study of Chen et al. (2010) suggest that accounting information quality is enhanced by adopting IFRS where quality is measured in terms of management performance and the level of discretionary accruals. However, IFRS is principle based standards which evoke more discretion by managers, that may lead to higher manipulation income figure presented in the financial statement (Barth et al., 2008). Jeanjean and Stolowy (2008) suggest that the objective of IFRS implementation may not be accomplished by reducing the practice of EM. Similar results is documented by Callao and Jarne (2010). However, literature suggest that IFRS offer more strict accounting practice in comparison to local accounting standards due to higher level transparency and comparability of the financial statement. Thus, the study hypothesizes that,

\section{$H_{1}$ : The adoption of IFRS has significant negative relationship with earnings management}

\subsection{Corporate Governance and Earnings Management}

Several studies conducted on the association between corporate governance and earnings management practices which is documented that the weak corporate governance induce earnings management practices within the firm (Abbadi, Hijazi, \& Al-Rahahleh, 2016; Abdelkarim \& Zuriqi, 2020; Habbash \& Alghamdi, 2016). Earlier studies evidence that firm value is linked with both internal and external corporate governance (Cremers \& Nair, 2005). Accordingly Brown and Caylor (2006) consider both internal and external issues of corporate governance and develop a firm specific corporate governance index based on Institutional Shareholder Services (ISS), which is considered for this study to develop CG index following previous studies (Moudud-Ul-Huq, 2015; Rahman, Al Bashir, Choudhury, \& Rabby, 2014; Rouf, 2011). Recent study of Abbadi et al. (2016) suggest that earnings management is negatively associated with the strength of corporate governance mirror through CGI which includes the characteristics of company's board and audit committee, external audit quality, financial reporting. Accordingly, this study assumes that,

\section{$\mathrm{H}_{2}$ : Corporate governance strength has significant negative relationship with earnings management}

\subsection{Moderating Effect Corporate Governance Strength on the Relationship Between IFRS and Earnings Management}

There is a lot of study in perspective of IFRS adoption, corporate governance, and earnings management. However, the study linked with these three variables under the same framework is only a few. Prior studies highlighted that the better accounting standards (e.g IFRS) and strong corporate governance have positive effect on accounting information quality which lead to better financial reporting quality by reducing the extent of earnings management (Ajina, Bouchareb, \& Souid, 2013; Al Matari, Al Swidi, \& Fadzil, 2014; Bayk \& Ramezanahmadi, 2016). According to Marra and Mazzola (2014) higher capacity of board during the adoption of IFRS restrain earnings management. In another study, Shawn, Jung, and Do (2015) identified that the IFRS adoption influence earnings management (i.e. reduce earnings manipulation), but only if the company has good governance. Recent study of Bonetti, Magnan, and Parbonetti (2016) documented that the firm with strong corporate governance measured by CG score, have experienced better accounting information quality in financial statements by reducing the extent of earnings management after the adoption of IFRS, even though the country have weak governance and low enforcement. Similarly, Liang and Shan (2013) documented that the earnings quality represent by accruals quality is improved following the implementation of IFRS only under the strong institutional settings which is measured by self constructed CG score. They also suggested for further study in relation to IFRS adoption and corporate governance. It is established by Baron and Kenny (1986) that the moderation is take place only when the following two conditions are satisfied: i) there is a strong relationship between moderating variables and dependent variables and ii) direct association between independent and dependent variables. A moderator is a qualitative or quantitative variable that affects the direction and/or strength of the relationship between independent variables and dependent variables. Moreover, in different study researchers use corporate governance as moderator to identify the outcome of corporate governance on financial reporting quality or earnings management (Al Matari et al., 2014; Bayk \& Ramezanahmadi, 2016; Dakata \& Hasn, 2016; Hui-Sung Kao \& Wei, 2014; Kouki \& Guizani, 2015; Nekhili, Amar, Chtioui, \& Lakhal, 2016; Surifah, 2017). It is apparent from the literature that there is a close affiliation among IFRS adoption, corporate governance and earnings management. Based on that, this study hypothesizes that: 


\section{$\mathrm{H}_{3}$ : Corporate Governance strength significantly moderate the relationship between IFRS and earnings management}

\section{Research Methodology}

\subsection{Sample Selection}

This study focus on the listed firms of Dhaka Stock Exchange (DSE) following IFRS adoption in Bangladesh which is covered 3 years each before and after the adoption of IFRS as BFRS by ICAB. The firms are selected based on the criteria that it must be listed in DSE and participate actively in the capital market for both tenure 2004-06 and 2013/14-15/16 of the study. The initial numbers of the listed firms and securities are 560 at the end of December, 2016 (DSE, 2016). Out of those number, securities listing (266), financial firms (100) and government owned company (8) which are operated under close supervision of Bangladesh central bank and concern regulatory bodies, are excluded for the study as like previous studies (Hasan, Molla, \& Khan, 2019; Ismail et al., 2013; Nouri \& Abaoub, 2014). Subsequently, few companies (92) are not considered for the study as the firm were not listed in both time periods and/or published annual report. Based on above discussion, the study comprise 94 firms listed in Dhaka Stock Exchange (DSE) for 6 years i.e. $(94 * 6)=564$ firm years observation.

\subsection{Research Model and Variable Definition}

The study is carried out with an objective to investigate the effect of IFRS adoption on EM in a developing economy which helps us to understand the change in financial reporting quality after the conversion of local accounting standards to international standards. Figure 1 presents theoretical framework of the study which highlighted independent, dependent and moderating variables.

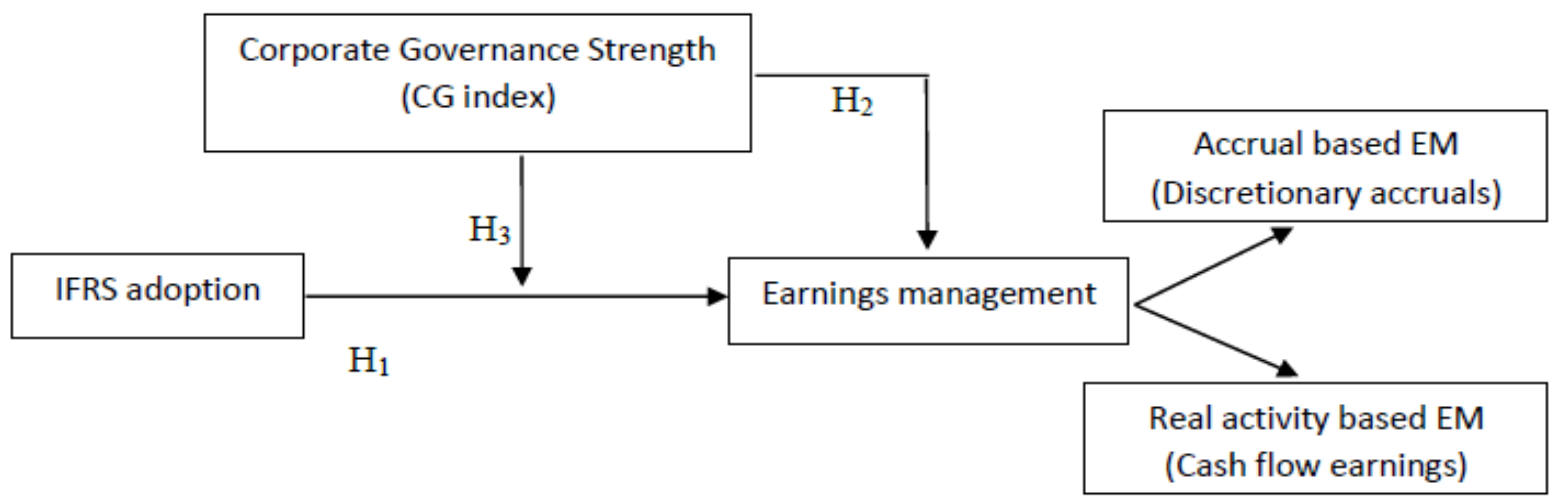

Figure 1. Study framework (Relation between IFRS adoption, corporate governance strength and earnings management)

To test the hypothesis, this study employs panel data in the course of multiple regression models which are related to IFRS adoption, CG and EM. The following variables are considered for those multiple regression to test the relationship among the variables: absolute value of discretionary accruals (|DA|) as dependent variable, IFRS adoption (IFRS) as independent variable and Corporate Governance Index (CGI) as moderating variable. The study also include a number of indicator and control variables in the study model by following previous research (Al-Rassas \& Kamardin, 2015; Hasan et al., 2019; Ismail, Dunstan, \& Van Zij1, 2010), namely audit quality (AQ) measured by the affiliation with big4 audit firms, company size in terms of assets (SIZE), structure of debt (LEV), yearly growth in terms of sales (GRT), return of assets (ROA). The specification of the study model is given below:

\section{Hypothesis 1: Effect of IFRS adoption on Earnings management}

$$
\begin{gathered}
\text { AB_DA } \\
\text { it }=\beta_{0}+\beta_{1} \mathrm{IFRS}_{\text {it }}+\beta_{2} \mathrm{AQ}_{\mathrm{it}}+\beta_{3} \mathrm{SIZE}_{\mathrm{it}}+\beta_{4} \mathrm{LEV}_{\mathrm{it}}+\beta_{5} \mathrm{GRT}_{\mathrm{it}}+\beta_{6} \mathrm{ROA}_{\mathrm{it}}+\varepsilon_{\mathrm{it}} \\
\mathrm{RM}_{\mathrm{it}}=\beta_{0}+\beta_{1} \mathrm{IFRS}_{\mathrm{it}}+\beta_{2} \mathrm{AQ}_{\mathrm{it}}+\beta_{3} \mathrm{SIZE}_{\mathrm{it}}+\beta_{4} \mathrm{LEV}_{\mathrm{it}}+\beta_{5} \mathrm{GRT}_{\mathrm{it}}+\beta_{6} \mathrm{ROA}_{\mathrm{it}}+\varepsilon_{\mathrm{it}}
\end{gathered}
$$

\section{Hypothesis 2: Effect of Corporate Governance on Earnings management}

$$
\begin{aligned}
& \mathrm{AB} \_\mathrm{DA}_{\mathrm{it}}=\beta_{0}+\beta_{1} \mathrm{CGI}_{\mathrm{it}}+\beta_{2} \mathrm{AQ}_{\mathrm{it}}+\beta_{3} \mathrm{SIZE}_{\mathrm{it}}+\beta_{4} \mathrm{LEV}_{\mathrm{it}}+\beta_{5} \mathrm{GRT}_{\mathrm{it}}+\beta_{6} \mathrm{ROA}_{\mathrm{it}}+\varepsilon_{\mathrm{it}} \\
& \mathrm{RM}_{\mathrm{it}}=\beta_{0}+\beta_{1} \mathrm{CGI}_{\mathrm{it}}+\beta_{2} \mathrm{AQ}_{\mathrm{it}}+\beta_{3} \mathrm{SIZE}_{\mathrm{it}}+\beta_{4} \mathrm{LEV}_{\mathrm{it}}+\beta_{5} \mathrm{GRT}_{\mathrm{it}}+\beta_{6} \mathrm{ROA}_{\mathrm{it}}+\varepsilon_{\mathrm{it}}
\end{aligned}
$$


Hypothesis 3: Moderating effect of Corporate Governance on the relationship between IFRS adoption and Earnings management

$$
\begin{gathered}
\text { AB_DA }_{\text {it }}=\beta_{0}+\beta_{1} \mathrm{IFRS}_{\text {it }}+\beta_{2} \mathrm{CGI}_{\mathrm{it}}+\beta_{3} \mathrm{IFRS}^{*} \mathrm{CGI}_{\mathrm{it}}+\beta_{4} \mathrm{AQ}_{\mathrm{it}}+\beta_{5} \mathrm{SIZE}_{\mathrm{it}}+\beta_{6} \mathrm{LEV}_{\mathrm{it}}+\beta_{7} \mathrm{GRT}_{\mathrm{it}}+\beta_{8} \mathrm{ROA}_{\mathrm{it}}+\varepsilon_{\mathrm{it}} \\
\mathrm{RM}_{\mathrm{it}}=\beta_{0}+\beta_{1} \mathrm{IFRS}_{\mathrm{it}}+\beta_{2} \mathrm{CGI}_{\mathrm{it}}+\beta_{3} \mathrm{IFRS}^{*} \mathrm{CGI}_{\mathrm{it}}+\beta_{4} \mathrm{AQ}_{\mathrm{it}}+\beta_{5} \mathrm{SIZE}_{\mathrm{it}}+\beta_{6} \mathrm{LEV}_{\mathrm{it}}+\beta_{7} \mathrm{GRT}_{\mathrm{it}}+\beta_{8} \mathrm{ROA}_{\mathrm{it}}+\varepsilon_{\mathrm{it}}
\end{gathered}
$$

Table 1 stand for the explanation of the functional variables in the regression model:

Table 1. Study variables clarification

\begin{tabular}{ll}
\hline Variables & Measurement \\
\hline $\begin{array}{l}\text { Absolute Discretionary Accruals } \\
\left(\mathrm{AB}_{\mathrm{D}} \mathrm{DA} \mathrm{it}_{\mathrm{it}}\right)\end{array}$ & $\begin{array}{l}\text { Absolute value of discretionary accruals of the firm 'i' in period 't', } \\
\text { calculated by the extended modified Jones model }\end{array}$ \\
\hline Real Earnings Management $\left(\mathrm{RM}_{\mathrm{it}}\right)$ & Aggregate value of ABN_PROD, ABN_CFO and ABN_DISEX \\
\hline IFRS adoption $\left(\mathrm{IFRS} \mathrm{it}_{\mathrm{it}}\right)$ & $\begin{array}{l}\text { IFRS adoption dummy }(0=\text { Pre IFRS, 2004-06; 1 = Post IFRS, } \\
\text { 2013/14-15/16) }\end{array}$ \\
\hline Corporate Governance Index $\left(\mathrm{CGI}_{\mathrm{it}}\right)$ & $\begin{array}{l}\text { Firm specific Corporate Governance Index (derived from CGI score } \\
\text { sheet) }\end{array}$ \\
\hline Audit Quality $\left(\mathrm{AQ} \mathrm{it}_{\mathrm{it}}\right)$ & $\begin{array}{l}\text { Dummy variable, equals } 1 \text { if a company is audited by Big4 auditors, } 0 \\
\text { otherwise }\end{array}$ \\
\hline Firm size $\left(\mathrm{SIZE}_{\mathrm{it}}\right)$ & Natural logarithm of average total assets \\
\hline Leverage $\left(\mathrm{LEV}_{\mathrm{it}}\right)$ & The ratio of total liabilities to total assets \\
\hline Growth $\left(\mathrm{GRT}_{\mathrm{it}}\right)$ & Annual percentage of changes in sales \\
\hline Return on Assets $\left(\mathrm{ROA}_{\mathrm{it}}\right)$ & Ratio of total income to average total assets \\
\hline
\end{tabular}

\subsection{Earnings Management Model Specification}

Earnings is considered as high quality when it provides precise information about the firm's performance which are relevant to the decision maker (Dechow et al., 2010). This study use discretionary accruals and real activities management as proxy of earnings management which are the mostly used and recognized proxy in literature by academicians (Ahmed, Neel, \& Wang, 2013; Alhadab, Clacher, \& Keasey, 2016; Ipino \& Parbonetti, 2016). Discretionary accruals is the fraction of total accruals which is considered as dependent variable (AB_DA) of this study and measured by extended modified Jones model (Yoon, Miller, \& Jiraporn, 2006) which is more appropriate compare to the modified Jones model due to better estimation and misspecification problems of the earlier models (Yoon, Kim, \& Woodruff, 2012). Islam, Ali, and Ahmad (2011) and Islam (2014) identified that the extended modified Jones model is more fit than modified Jones model for Bangladesh in terms of $\mathrm{R}^{2}$ value which is $83.8 \%$ for extended modified Jones model compare to $8.9 \%$ for modified Jones model. The proposed model for accruals estimation is presented in table 3 which explains that the total accruals mainly depends on three transforming factors: i) revenue from cash sales, ii) expenses in cash and iii) non-cash expenses including depreciation and retirement benefit expenses.

Table 2. Model for earnings management detection

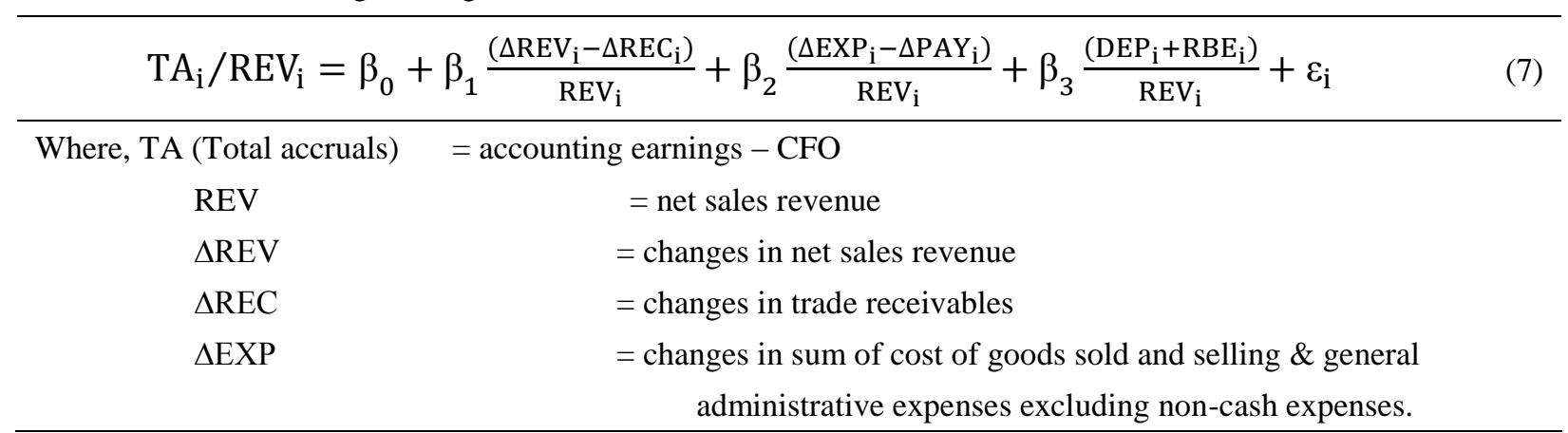




\begin{tabular}{|c|c|}
\hline$\triangle \mathrm{PAY}$ & $=$ changes in trade payables \\
\hline DEP & $=$ depreciation expenses \\
\hline RBE & $=$ retirement benefits expenses \\
\hline
\end{tabular}

Here, $b_{k}$ represents the estimated coefficients of $\beta_{k}$ in equation (3.1). The discretionary accruals (DA) obtained from the equation (2) represent the differences between actual total accruals and the expected (non-discretionary) total accruals.

Following Roychowdhury (2006) the study consider three approach for real activities manipulation: 1) Accelerated sales following by higher sales discount or convenient credit facility. 2) Lower cost of goods sold due to excessive production. 3) Insistently dropping aggregate discretionary expenses which includes advertising expenses, sales, general and administrative expenses, to improve net margin reported in the financial statements. Similar approach is applied by Zang (2011), Cohen and Zarowin (2010), Cohen, Mashruwala, and Zach (2010), Doukakis (2014) as well as Ipino and Parbonetti (2016) and provide evidence that those three metrics are useful to identify the real activities manipulation. Accordingly, this study consider accelerated sales, lower COGS and lower discretionary expenses to recognize real activities management which are decomposed in table 3.

Table 3. Decomposition of CFO, production cost and discretionary expenses

$$
\frac{\text { CFO }_{i t}}{\operatorname{ASSETS~}_{i, t-1}}=\beta_{0}+\beta_{1} \frac{1}{\operatorname{ASSETS}_{i, t-1}}+\beta_{2} \frac{\text { SALES }_{i t}}{\operatorname{ASSETS}_{i, t-1}}+\beta_{3} \frac{\Delta S A L E S_{i t}}{\operatorname{ASSETS}_{i, t-1}}+\varepsilon_{i t}
$$

CFOit $=$ cash flows from operations taken from the statement of cash flows. Abnormal cash flow from operations is the actual CFO less the normal level of CFO calculated with the estimated coefficient from equation (9)

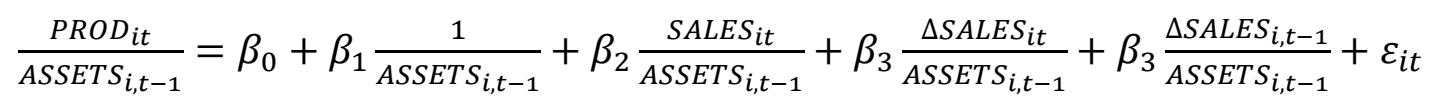

where PRODit $=$ production costs, defined as the sum of cost of goods sold and the change in inventories from year $\mathrm{t}-1$ to year t;

$$
\frac{\operatorname{DISEX}_{i t}}{\operatorname{ASSETS}_{i, t-1}}=\beta_{0}+\beta_{1} \frac{1}{\operatorname{ASSETS}_{i, t-1}}+\beta_{2} \frac{\operatorname{SALES}_{i t-1}}{\operatorname{ASSETS}_{i, t-1}}+\varepsilon_{i t}
$$

DISEXit $=$ discretionary expenses defined as selling, general and administrative expenses for year $\mathrm{t}$.

\subsection{Corporate Governance Index (CGI)}

Prior studies employ corporate governance index to evaluate the effectiveness of corporate governance practices or the compliance status of the company (Brown \& Caylor, 2006; Ferdous, 2013; Mallin \& Ow-Yong, 2013; Sathye, Islam, \& Hu, 2014). This study measured corporate governance strength in terms of corporate governance index (CGI) which is developed by considering the framework (where applicable) given by Brown and Caylor (2006). Similar type of framework is also used by Salleh (2009) in Malaysian context, Moudud-Ul-Huq (2015) and Rahman et al. (2014) in Bangladesh context as well as other researcher in different perspectives (Bonetti et al., 2016; Cormier, 2014) to construct corporate governance index. Brown and Caylor (2006) employ Institutional Shareholder Service's (ISS) data to measure the firm specific corporate governance index and following that this study measured corporate governance index (CGI) based on the issue of compliance and non-compliance with particular corporate governance provision. The study use dichotomous approach for indexing, where ' 1 ' (one) is given for compliance and ' 0 ' (zero) for non-compliance. Corporate governance strength of each company is articulated by the index value which is derived from the equation 12.

$$
\text { Firm Specific Corporate Governance Index }\left(\mathrm{CGI}_{\mathrm{it}}\right)=\left(\sum \mathrm{CGP}_{\mathrm{it}} / \mathrm{MPS}\right)
$$

Here, 
$\mathrm{CGP}_{\text {it }}$ - Score of each corporate governance provision for company in a period

MPS $_{\text {it }}$ - Maximum possible score for company in a period

Corporate governance index is developed based on seven broad categories which has fifty (50) corporate governance provisions (Appendix 1). Few corporate governance provisions (e.g. compensation) used by Brown and Caylor (2006) are not considered for CG index because of non-relevance in the context of CG guidelines of Bangladesh (BSEC, 2012). To measure the Corporate Governance Index (CGI), this study use un-weighted approach where all items have same value and importance. This approach is more appropriate due to the same level of importance given to the selected items and less scope of arbitrary judgment on the relative issues (Manawaduge, 2012).

\section{Findings and Analysis}

\subsection{Descriptive Analysis}

The annual report of the firm is used to extract data required for the study. Following the data collection, the value of discretionary accruals and aggregate value of real earnings are estimated by applying extended modified Jones model (Yoon et al., 2006) and Roychowdhury model (Roychowdhury, 2006) respectively. Table 4 characterize mean of the absolute value of discretionary accruals (AB_DA) which is 0.0413 with standard deviation of 0.0963 , similar to the study of Humayun Kabir, Sharma, Islam, and Salat (2011); Houqe, Van Zijl, Dunstan, and Karim (2010). At the same time, real earnings activities (i.e. aggregate value of abnormal cash flow from operations, abnormal discretionary expenses and abnormal production costs) represents the mean value of 3.37e-09 with the standard deviation of 0.5830; similar to the study of Bhuiyan (2015), where minimum value is -2.472 and maximum value is 2.702, which means that the company are engaged in real earnings management in both direction. CGI score represents the strength of corporate governance, which is range from minimum 0.24 to maximum 0.96 . The mean value of the CGI score is 0.6256 with standard deviation of 0.2519 , which is similar to the study Moudud-Ul-Huq (2015) and Bhuiyan, Ullah, and Biswas (2007).

Table 4. Descriptive statistics $(\mathrm{n}=94, \mathrm{t}=6)$

\begin{tabular}{lllll}
\hline Variables & Mean & Std. Deviation & Minimum & Maximum \\
\hline AB_DA & 0.0413 & 0.0963 & 0.00006 & 0.9737 \\
\hline RM & $3.37 \mathrm{e}-09$ & 0.5830 & -2.4720 & 2.7027 \\
\hline CGI & 0.6256 & 0.2519 & 0.24 & 0.96 \\
\hline AQ & 0.1401 & 0.3473 & 0 & 1 \\
\hline SIZE & 8.9103 & 0.6458 & 7.2784 & 10.9799 \\
\hline LEV & 0.5890 & 0.4541 & 0.0235 & 6.6216 \\
\hline GRT & 0.1127 & 0.4625 & -1 & 4.3968 \\
\hline ROA & 0.0298 & 0.0911 & -1.0021 & 0.2667 \\
\hline
\end{tabular}

AB_DA for Absolute value of Discretionary accruals; RM for Real Earnings Management; CGI for Corporate Governance Index; AQ for Audit Quality; SIZE is natural logarithm of total assets; LEV for Leverage; GRT for Growth of sales revenue; ROA for Return on Assets.

\subsection{Correlation Matrix and Multicollinearity}

Correlation analysis is applied to get information about the strength of relationship and direction among the variables (Pallant, 2011). This study performed correlation analysis to reveal the relationship and direction among dependent, independent and control variables. 
Table 5. Correlation matrix

\begin{tabular}{|c|c|c|c|c|c|c|c|c|c|}
\hline & AB_DA & IFRS & RM & CGI & $\mathrm{AQ}$ & SIZE & LEV & GRT & ROA \\
\hline AB_DA & 1.000 & & & & & & & & \\
\hline IFRS & $-0.246 * * *$ & 1.000 & & & & & & & \\
\hline $\mathrm{RM}$ & $0.214 * * *$ & $0.553 * * *$ & 1.000 & & & & & & \\
\hline CGI & $-0.172 * * *$ & $0.927 * * *$ & $0.532 * * *$ & 1.000 & & & & & \\
\hline AQ & $0.253^{* * *}$ & -0.035 & -0.053 & 0.046 & 1.000 & & & & \\
\hline SIZE & $0.337 * * *$ & $0.315^{* * *}$ & $-0.074 *$ & $0.390 * * *$ & $0.309 * * *$ & 1.000 & & & \\
\hline LEV & 0.043 & -0.051 & $0.097 * *$ & $-0.074 *$ & -0.039 & $-0.083 * *$ & 1.000 & & \\
\hline GRT & 0.033 & $-0.084 * *$ & 0.008 & -0.046 & 0.002 & -0.004 & $0.072 *$ & 1.000 & \\
\hline $\mathrm{ROA}$ & -0.054 & 0.031 & $-0.131 * * *$ & $0.078 *$ & $0.224 * * *$ & $0.166 * * *$ & $-0.606 * * *$ & $0.087 * *$ & 1.000 \\
\hline
\end{tabular}

$* * *$ significance at $1 \%$ level, $* *$ at $5 \%$ and $*$ at $10 \%$ level

Table 5 shows correlation matrix which represent the relationship and direction among all study variables. The table shows that there is significant negative correlation between IFRS and AB_DA which means that IFRS adoption may reduce the extent of EM in view of discretionary accruals (Barth et al., 2008; Chen et al., 2010). Similar result is documented for the relationship between CGI and AB_DA which means that better corporate governance may guide to lower level of discretionary accruals (Abbadi et al., 2016; Bekiris \& Doukakis, 2011). Except one, all variables have correlation below 0.90 which shows that there is no sign of multicollinearity. Only exception is the relationship between IFRS and CGI i.e. 0.927 which may be the cause of dummy variable (Allison, 2012) represent by IFRS. For further investigation of this issue, this study check the VIF and tolerance value. Literature suggest that, the VIF and tolerance value is more appropriate to identify the issue of multicollinearity (Hamilton, 2012). A range of acceptable VIF value is mentioned in the literature. The rule of thumb is that the VIF value should be below 10 which is mostly recommended in the literature (Allison, 2012; Hair, Black, Babin, Anderson, \& Tatham, 2006). Table 6 represent the VIF and tolerance value of the different regression model and it shows that none of the VIF score cross the cut off level or more than 10. Accordingly, it can be mentioned that none of the model have issue of multicollinearity.

Table 6. VIF and tolerance value

\begin{tabular}{lllllll}
\hline $\begin{array}{l}\text { Name } \\
\text { variable }\end{array}$ & the & $\begin{array}{l}\text { Regression model } \mathbf{( 1 ~ \& ~} \\
\mathbf{2})\end{array}$ & $\begin{array}{l}\text { Regression model } \\
\mathbf{( 3 ~ \& ~ 4 )}\end{array}$ & $\begin{array}{l}\text { Regression model } \\
\mathbf{5} \text { \& 6) }\end{array}$ & \\
\cline { 2 - 7 } & VIF & $\begin{array}{l}\text { Tolerance } \\
\text { value }\end{array}$ & VIF & $\begin{array}{l}\text { Tolerance } \\
\text { value }\end{array}$ & VIF & $\begin{array}{l}\text { Tolerance } \\
\text { value }\end{array}$ \\
\hline IFRS & 1.74 & 0.574 & - & - & 7.81 & 0.128 \\
\hline CGI & - & - & 1.20 & 0.832 & 8.12 & 0.123 \\
\hline AQ & 1.18 & 0.850 & 1.14 & 0.874 & 1.18 & 0.848 \\
\hline SIZE & 1.37 & 0.729 & 1.37 & 0.729 & 1.38 & 0.727 \\
\hline LEV & 1.09 & 0.920 & 1.08 & 0.923 & 1.08 & 0.922 \\
\hline GRT & 1.03 & 0.966 & 1.03 & 0.974 & 1.04 & 0.962 \\
\hline ROE & 1.13 & 0.882 & 1.13 & 0.883 & 1.13 & 0.883 \\
\hline
\end{tabular}

\subsection{Test for Normality and Autocorrelation}

Jarque-Bera normality test shows that the data is normal as p-value is insignificant which refers to null hypothesis is accepted. The study conduct Wooldridge test for autocorrelation to check the issue of serial autocorrelation, which indicates that there is no serial autocorrelation, as p-value is insignificant i.e. null hypothesis is accepted. In addition, Ramsey RESET test is done to identify the issue of endogeneity problems. Result shows that the model does not have any such issue, $\mathrm{p}$-value insignificant (Prob $>\mathrm{F}=0.6231$ ), means accept the null hypothesis which refers to unlikely present of any misspecification problem in the model (Adib \& Xianzhi, 2019; Ramsey, 1969). 
Table 7. Test for normality and autocorrelation

\begin{tabular}{|c|c|}
\hline Name of the Test & Outcome \\
\hline \multirow[t]{2}{*}{ Jarque-Bera normality test } & 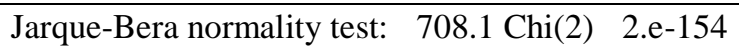 \\
\hline & Jarque-Bera test for Ho: normality: \\
\hline \multirow{3}{*}{$\begin{array}{lcc}\text { Wooldridge test } & \text { for } \\
\text { autocorrelation in panel data } & \end{array}$} & H0: no first order autocorrelation \\
\hline & 0.218 \\
\hline & 0.6419 \\
\hline \multirow[t]{3}{*}{ Ramsey RESET test } & Ho: model has no omitted variables \\
\hline & $\mathrm{F}(3,552)=$ \\
\hline & Prob $>F=$ \\
\hline
\end{tabular}

\subsection{Test for Heteroskedasticity}

Beside the issue of multicollinearity, normality of data and autocorrelation, the study needs to check the issue of heteroskedasticity. Following the assumption of heteroskedasticity i.e. variance of the data set are not invariable, in OLS regression model, Breusch-Pagan / Cook-Weisberg test and White test for heteroskedasticity are carried out and it shows that data are not homoscedasticity, as p-value in both cases are significant, i.e. null hypothesis is rejected, present in table 8. Earlier literature suggests that the residual are independent in case of panel data. Based on the outcome of study data, OLS regression model is run with the check of robustness to address the issue of heteroskedasticity and to ensure best estimation of the model (Adib \& Xianzhi, 2019; Deboskey \& Luo, 2018; Meangbua, Dhakal, \& Kuwornu, 2019)

Table 8 . Test for heteroskedasticity

\begin{tabular}{lc}
\hline Name of the Test & Outcome \\
\hline Breusch-Pagan / Cook-Weisberg test & Breusch-Pagan / Cook-Weisberg test for heteroskedasticity \\
Ho: Constant variance & chi2(1) $=47.41$ \\
Prob $>$ chi2 $=$ & 0.0000 \\
\hline White's test & White's test for Ho: homoskedasticity \\
against Ha: unrestricted heteroskedasticity \\
chi2(58) $=167.44$ \\
Prob $>$ chi2 $=0.0000$
\end{tabular}

\subsection{Regression Model Specification}

The study needs to specify the model which is applied for data analysis. In the model specification procedure of panel data, the first step is to compare pooled OLS model and random effect model (GLS) to identify the most appropriate model. Breusch and Pagan Lagrangian multiplier test for random effects was conducted which shows that the random effect model is more appropriate than the pooled OLS model, as P-value of the test is significant at $1 \%$ level.

Table 9. Breusch and Pagan LM test

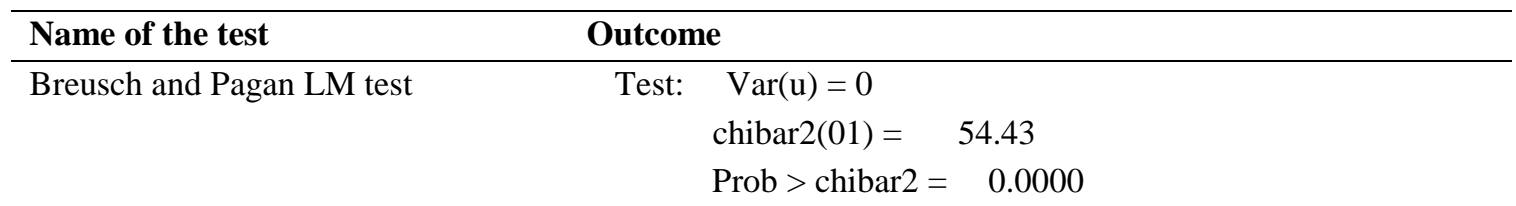

Next, Hausman specification test is conducted to identify the most appropriate model between the random effect and fixed effect model. The result of Hausman test shows that the random effect model is more appropriate than the fixed 
effect model, as p-value is Prob $>$ chi2 $=0.8342$, which is not significant. The result of Hausman test is presented in table 10 .

Table 10. Result of Hausman test

\begin{tabular}{lcl}
\hline Name of the test & Outcome & \\
\hline Hausman specification test & Test: & Ho: difference in coefficients not systematic \\
& chi2 $(6)=(b-B)^{\prime}\left[\left(V_{-} b-V \_B\right)^{\wedge}(-1)\right](b-B)=2.79$ \\
& Prob $>$ chi2 $=\quad 0.8342$
\end{tabular}

Accordingly, the study applied random effect regression model for better estimation. Moreover, random effect model is applied with robust standards error to overcome the issue of heteroskadasticity (Adib \& Xianzhi, 2019; Deboskey \& Luo, 2018).

\subsection{Regression Results}

Table 11 presents the regression result of equation (1) to (6), with both proxy of earnings management. The coefficient of the intercepts (constant) for all equations are significant at $1 \%$ level and $\mathrm{R}^{2}$ value for all models are range from $(0.258)$ to $(0.3555)$. Similar $\mathrm{R}^{2}$ value of regression model is documented in literature for this type of study (den Besten, Georgakopoulos, Vasileiou, \& Ereiotis, 2015; Houqe et al., 2010; Humayun Kabir et al., 2011). Result shows that IFRS and CG both have significant negative relationship with absolute value of discretionary accruals and real earnings management. It implies that the introduction of IFRS and the presence of good corporate governance help to reduce the level of earnings management which is factual for both types of earning management in Bangladesh. Similar results are recognized in the literature where researchers have documented significant negative association between corporate governance strength and earnings management (Abbadi et al., 2016; Bouchareb, Ajina, \& Souid, 2014; Ho, Liao, \& Taylor, 2015; Jiang, Zhu, \& Huang, 2013).

Table 11. Result of equation (1) to (6), using Random effect GLS regression with robust

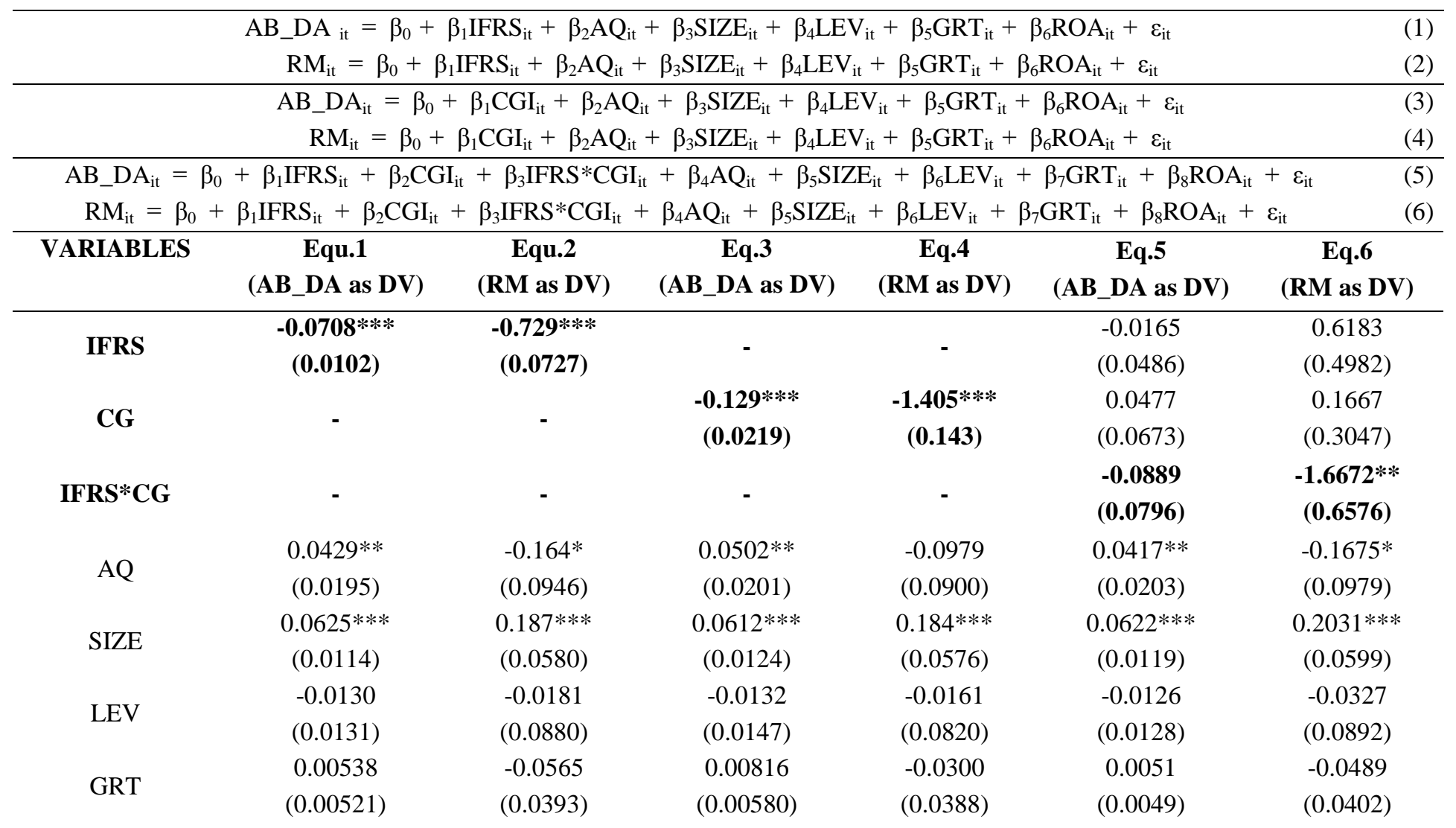




\begin{tabular}{ccccccc} 
ROA & $-0.213^{*}$ & -0.251 & $-0.215^{*}$ & -0.315 & $-0.2087 *$ & -0.2120 \\
& $(0.116)$ & $(0.648)$ & $(0.124)$ & $(0.621)$ & $(0.1196)$ & $(0.6234)$ \\
Constant & $-0.478^{* * *}$ & $-1.142^{* *}$ & $-0.423 * * *$ & $-0.627 *$ & $-0.4913 * * *$ & $-1.3649 * * *$ \\
Observations & $(0.0932)$ & $(0.512)$ & $(0.0947)$ & $(0.501)$ & $(0.0885)$ & $(0.5056)$ \\
No. of Co. & 564 & 564 & 564 & 564 & 564 & 564 \\
$\mathrm{R}^{2}$ & 94 & 94 & 94 & 94 & 94 & 94 \\
Prob>Chi2 & 0.2832 & 0.3457 & 0.258 & 0.3208 & 0.2861 & 0.3555 \\
\hline
\end{tabular}

Robust standard errors in parentheses: *** $\mathrm{p}<0.01, * * \mathrm{p}<0.05, * \mathrm{p}<0.1$

AB_DA means Absolute value of Discretionary accruals; RM means Real earnings management; IFRS adoption as dichotomous variable; CG means corporate governance; AQ for Audit Quality; SIZE for Size of the company in terms of total assets; LEV for Leverage; GRT for Growth in terms of sales revenue; ROA for Return on Assets.

Moreover, the moderating effect of corporate governance index (CGI) on the relationship between IFRS and earnings management is estimated in Eq.5 and Eq.6. The result shows that corporate governance index (CGI) negatively moderates the relationship between IFRS and RM. The direct positive relationship between IFRS and RM, changes to negative relationship (-1.66) at 5\% level of significance. It means that the adoption of IFRS reduce the level of real earnings management in presence of good corporate governance. Similarly, Hastuti, Ghozali, and Yuyetta (2016) documented that internal control structure negatively moderate the relationship between IFRS and RM. However, CG does not have influence on the relationship between IFRS and discretionary accruals. Besides, audit quality and size of the company have significant influence on the practice of earnings management.

\section{Conclusion}

This study focused on the relationship between IFRS adoption and earnings management in Bangladesh. To the best of researcher knowledge, this study is one of very few which examine the effect of IFRS adoption on both proxy of EM, namely discretionary accruals and real activities management. Moreover, this study investigates the moderating role of corporate governance strength on the relationship between IFRS adoption and EM for the very first time. The results of the study shows that IFRS adoption has significant negative effect on both earnings management proxies, i.e. it helps to reduce the level of EM. Similar results are documented for the relationship between corporate governance strength and earnings management. Moreover, this study explore that corporate governance strength significantly moderates the relationship between IFRS adoption and real earnings management. The study has theoretical, practical and policy implication as well as methodical and academic contribution in the context of IFRS adoption in developing country like Bangladesh. Hence, the application of IFRS by Bangladesh can serve as an exemplary nation for other least developed countries. Accordingly, this study can be beneficial for the member of the regulatory bodies and researchers to formulate new policy and enhance corporate governance practices. Future studies may also investigate the interacting effect of corporate governance strength on other related variables which may influence the level of earnings management.

\section{References}

Abbadi, S. S., Hijazi, Q. F., \& Al-Rahahleh, A. S. (2016). Corporate Governance Quality and Earnings Management: Evidence from Jordan. Australasian Accounting, Business and Finance Journal, 10(2), 54-75.

Abdelkarim, N., \& Zuriqi, K. (2020). Corporate Governance and Earnings Management: Evidence from Listed Firms at Palestine Exchange. Asian Economic and Financial Review, 10(2), 200-217.

Adib, M., \& Xianzhi, Z. (2019). Board Characteristics and Corporate Social Performance Nexus - A Multi-Theoretical Analysis - Evidence from South Africa.

Ahmed, A. S., Neel, M., \& Wang, D. (2013). Does mandatory adoption of IFRS improve accounting quality? Preliminary evidence. Contemporary Accounting Research, 30(4), 1344-1372.

Ajina, A., Bouchareb, M., \& Souid, S. (2013). Corporate governance mechanisms and earnings management after and before the adoption of IFRS. The Business \& Management Review, 3(4), 147.

Al-Rassas, A. H., \& Kamardin, H. (2015). Internal and external audit attributes, audit committee characteristics, ownership concentration and earnings quality: Evidence from Malaysia. Mediterranean Journal of Social Sciences, 6(3), 458-470. https://doi.org/10.5901/mjss.2015.v6n3p458 
Al Matari, E. M., Al Swidi, A. K., \& Fadzil, F. H. B. (2014). The moderating effect of board diversity on the relationship between executive committee characteristics and firm performance in Oman: Empirical Study. Asian Social Science, 10(12), 6.

Alhadab, M., Clacher, I., \& Keasey, K. (2016). A Comparative Analysis of Real and Accrual Earnings Management around Initial Public Offerings under Different Regulatory Environments. Journal of Business Finance \& Accounting, 43(7-8), 849-871.

Allison, P. (2012). When Can You Safely Ignore Multicollinearity? Retrieved April 25, 2019, from https://statisticalhorizons.com/multicollinearity

Ball, R. (2001). Infrastructure requirements for an economically efficient system of public financial reporting and disclosure. Brookings-Wharton papers on financial services, 2001(1), 127-169.

Baron, R. M., \& Kenny, D. A. (1986). The moderator-mediator variable distinction in social psychological research: Conceptual, strategic, and statistical considerations. Journal of personality and social psychology, 51(6), 1173.

Barth, M. E., Landsman, W. R., \& Lang, M. H. (2008). International accounting standards and accounting quality. Journal of Accounting Research, 46(3), 467-498.

Bayk, M., \& Ramezanahmadi, M. (2016). Studying the moderating effect of the corporate governance on the relationship between accounting conservatism and earnings management on the Stock Exchange. International Journal of Humanities and Cultural Studies (IJHCS).

Bekiris, F. V., \& Doukakis, L. C. (2011). Corporate governance and accruals earnings management. Managerial and Decision Economics, 32(7), 439-456.

Bhuiyan, M., Ullah, H., \& Biswas, P. K. (2007). Corporate Governance and Reporting: An Empirical Study of the Listed Companies in Bangladesh. Dhaka University Journal of Business Studies, 28(1).

Bhuiyan, M. H. U. (2015). Earnings Management to Exceed Earnings Threshold: Evidence from Bangladesh. Journal of Business Studies, XXXVI(3).

Bonetti, P., Magnan, M. L., \& Parbonetti, A. (2016). The Influence of Country-and Firm-level Governance on Financial Reporting Quality: Revisiting the Evidence. Journal of Business Finance \& Accounting, 43(9-10), 1059-1094.

Bouchareb, M., Ajina, A., \& Souid, S. (2014). Does the Adoption of IAS/IFRS with a Strong Governance Mechanism Can Deter Earnings Management?. International Journal of Academic Research in Economics and Management Sciences, 3(1), 264.

Brown, L. D., \& Caylor, M. L. (2006). Corporate governance and firm valuation. Journal of accounting and public policy, 25(4), 409-434.

Brüggemann, U., Hitz, J.-M., \& Sellhorn, T. (2013). Intended and unintended consequences of mandatory IFRS adoption: A review of extant evidence and suggestions for future research. European Accounting Review, 22(1), 1-37.

BSEC. (2012). Corporate Governance Guidelines For Bangladesh (Vol. SEC/CMRRCD/2006-158/134/Admin/44). Bangladesh: Bangladesh Securities and Exchange Commission.

Byard, D., Li, Y., \& Yu, Y. (2011). The effect of mandatory IFRS adoption on financial analysts' information environment. Journal of Accounting Research, 49(1), 69-96.

Cai, L., Rahman, A. R., \& Courtenay, S. M. (2008). The effect of IFRS and its enforcement on earnings management: An international comparison. Paper presented at the Massey University.

Callao, S., \& Jarne, J. I. (2010). Have IFRS affected earnings management in the European Union?. Accounting in Europe, 7(2), 159-189.

Chen, H., Tang, Q., Jiang, Y., \& Lin, Z. (2010). The role of international financial reporting standards in accounting quality: Evidence from the European Union. Journal of International Financial Management \& Accounting, 21(3), 220-278.

Chua, Y. L., Cheong, C. S., \& Gould, G. (2012). The impact of mandatory IFRS adoption on accounting quality: Evidence from Australia. Journal of International Accounting Research, 11(1), 119-146.

Cohen, D. A., Mashruwala, R., \& Zach, T. (2010). The use of advertising activities to meet earnings benchmarks: Evidence from monthly data. Review of Accounting Studies, 15(4), 808-832. 
Cohen, D. A., \& Zarowin, P. (2010). Accrual-based and real earnings management activities around seasoned equity offerings. Journal of Accounting and Economics, 50(1), 2-19.

Cormier, D. (2014). The Incidence of Corporate Governance and IFRS on Information Asymmetry and the Value Relevance of Earnings: Some Canadian Evidence. Cahier de recherche, 1. Retrieved from http://www.cifo.uqam.ca/publications/pdf/2014-01.pdf

Cremers, K., \& Nair, V. B. (2005). Governance mechanisms and equity prices. The Journal of Finance, 60(6), 2859-2894.

Dakata, M. N., \& Hasn, K. (2016). IFRS Adoption and Earnings Management: Moderating Role of Institutional Ownership in Nigeria. International Journal of Management Research and Reviews, 6(12), 1685.

Deboskey, D., \& Luo, Y. (2018). Recent trends in corporate political disclosure for a sample of S\&P 500 firms: a new and emerging corporate disclosure area (Vol. 15).

Dechow, P., Ge, W., \& Schrand, C. (2010). Understanding earnings quality: A review of the proxies, their determinants and their consequences. Journal of Accounting and Economics, 50(2), 344-401.

den Besten, P. S., Georgakopoulos, G., Vasileiou, K. Z., \& Ereiotis, N. (2015). The Impact of IFRS Adoption on Earnings Quality: A Study Conducted on Foreign Issuers in the United States. International Business Research, $8(11), 139$.

Doukakis, L. C. (2014). The effect of mandatory IFRS adoption on real and accrual-based earnings management activities. Journal of Accounting and Public Policy, 33(6), 551-572.

DSE. (2016). Performance of DSE at a Glance. Retrieved December 14, 2016, from http://www.dsebd.org/mglc.php

El Diri, M., Lambrinoudakis, C., \& Alhadab, M. (2020). Corporate governance and earnings management in concentrated markets. Journal of Business Research, 108, 291-306.

Fama, E. F. (1980). Agency Problems and the Theory of the Firm. The Journal of Political Economy, 88(2), 288-307.

Ferdous, C. S. (2013). Compliance with codes of corporate governance in developing economies: The case of Bangladesh. (Doctor of Philosophy), University of Birmingham. Retrieved from http://etheses.bham.ac.uk/3993/

Frankel, R., \& Li, X. (2004). Characteristics of a firm's information environment and the information asymmetry between insiders and outsiders. Journal of Accounting and Economics, 37(2), 229-259.

Gordon, E., Jorgensen, B., \& Linthicum, C. (2011). Could IFRS replace US GAAP? A comparison of earnings attributes and informativeness in the US market. Working paper. Retrieved from http://www.fox.temple.edu/conferences/cav/2008/documents/gordonpaper.pdf

Habbash, M., \& Alghamdi, S. (2016). Audit quality and earnings management in less developed economies: the case of Saudi Arabia. Journal of Management \& Governance, 1-23. https://doi.org/10.1007/s10997-016-9347-3

Hair, J. F., Black, W. C., Babin, B. J., Anderson, R. E., \& Tatham, R. L. (2006). Multivariate data analysis (Vol. 6): Pearson Prentice Hall Upper Saddle River. NJ.

Hamilton, L. C. (2012). Statistics with Stata: version 12. Cengage Learning.

Hasan, M. S., Hossain, S. Z., \& Rahman, R. A. (2014). Corporate governance and corporate accruals: the situation in Bangladesh. Aestimatio, (9), 90.

Hasan, M. T., Molla, M. S., \& Khan, F. (2019). Effect of board and audit committee characteristics on profitability: Evidence from pharmaceutical and chemical industries in Bangladesh. Finance \& Economics Review, 1(1), 64-76.

Hasan, M. T., \& Rahman, A. A. (2017). IFRS Adoption and earnings management: A review and justification of earnings management model for developing countries. ELK Asia Pacific Journal of Finance and Risk Management, 8(3), 43-60. https://doi.org/10.16962/EAPJFRM/issn

Hasan, M. T., \& Rahman, A. A. (2019). Conceptual framework for IFRS adoption, audit quality and earnings management: The case of Bangladesh. International Business and Accounting Research Journal, 3(1).

Hastuti, T. D., Ghozali, I., \& Yuyetta, E. N. A. (2016). The effect of international financial reporting standars on the real earnings management and internal control structure as a moderating variable. International Journal of Economics and Financial Issues, 6(4), 1807-1814. 
Ho, L. C. J., Liao, Q., \& Taylor, M. (2015). Real and Accrual-Based Earnings Management in the Pre-and Post-IFRS Periods: Evidence from China. Journal of International Financial Management \& Accounting, 26(3), 294-335.

Houqe, N., Van Zijl, T., Dunstan, K. L., \& Karim, A. (2010). Does Corporate Governance affect Earnings Quality: Evidence from an Emerging Market. Academy of Taiwan, Business Management Review, 7(3), 48-57.

Hui-Sung Kao, \& Wei, T.-H. (2014). The effect of IFRS, information asymmetry and corporate governance on the quality of accounting information. Asian Economic and Financial Review, 4(2), 226.

Humayun Kabir, M., Sharma, D., Islam, A., \& Salat, A. (2011). Big 4 auditor affiliation and accruals quality in Bangladesh. Managerial Auditing Journal, 26(2), 161-181.

Iatridis, G. (2010). International Financial Reporting Standards and the quality of financial statement information. International Review of Financial Analysis, 19(3), 193-204.

Ipino, E., \& Parbonetti, A. (2016). Mandatory IFRS adoption: the trade-off between accrual-based and real earnings management. Accounting and Business Research, 1(31), 91-121. https://doi.org/10.1080/00014788.2016.1238293

Islam, M. A. (2014). How Earnings Are Managed? Evidence from a Developing Country. The Social Sciences, 9(5), 321-334.

Islam, M. A., Ali, R., \& Ahmad, Z. (2011). Is modified Jones model effective in detecting earnings management? Evidence from a developing economy. International Journal of Economics and Finance, 3(2), 116.

Ismail, W. A. W., Dunstan, K., \& Van Zijl, T. (2010). Earnings quality and corporate governance following the implementation of Malaysian code of corporate governance. Paper presented at the the Journal of Contemporary Accounting and Economics (JCAE) and Seoul National University joint symposium, Seoul, South Korea. Retrieved from https://www.researchgate.net/profile/Wan_Adibah_Wan_Ismail/publication/228121833_Earnings_Quality_and _Corporate_Governance_Following_the_Implementation_of_Malaysian_Code_of_Corporate_Governance/links /0deec52d24feac7bff000000.pdf

Ismail, W. A. W., Kamarudin, K. A., Zijl, T. V., \& Dunstan, K. (2013). Earnings quality and the adoption of IFRS-based accounting standards: Evidence from an emerging market. Asian review of accounting, 21(1), 53-73.

Jeanjean, T., \& Stolowy, H. (2008). Do accounting standards matter? An exploratory analysis of earnings management before and after IFRS adoption. Journal of accounting and public policy, 27(6), 480-494.

Jensen, M. C., \& Meckling, W. H. (1976). Theory of the firm: Managerial behavior, agency costs and ownership structure. Journal of Financial Economics, 3(4), 305-360.

Jiang, F., Zhu, B., \& Huang, J. (2013). CEO's financial experience and earnings management. Journal of Multinational Financial Management, 23(3), 134-145.

Judge, W., Li, S., \& Pinsker, R. (2010). National adoption of international accounting standards: An institutional perspective. Corporate Governance: An International Review, 18(3), 161-174.

Kaaya, I. D. (2015). The Intenational Financial Reporting Standards (IFRS) and Value Relevance: A Review of Empirical Evidence. Journal of Finance and Accounting, 3(3), 37-46. https://doi.org/10.12691/jfa-3-3-3

Key, K. G., \& Kim, J. Y. (2020). IFRS and accounting quality: Additional evidence from Korea. Journal of International Accounting, Auditing and Taxation, 100306.

Kouki, M., \& Guizani, M. (2015). Outside directors and firm performance: The moderating effects of ownership and board leadership structure. International Business Research, 8(6), 104.

Liang, J., \& Shan, Y. G. (2013). Do Corporate Governance Mechanisms Impact on Earnings Quality? Evidence from IFRS Adoption in European Union. https://doi.org/10.2139/ssrn.2215424

Liu, C., Yao, L. J., Hu, N., \& Liu, L. (2011). The impact of IFRS on accounting quality in a regulated market: An empirical study of China. Journal of Accounting, Auditing \& Finance, 26(4), 659-676. https://doi.org/10.1177/0148558X11409164

Mallin, C., \& Ow-Yong, K. (2013). The Development of the UK Alternative Investment Market: Its Growth and Governance Challenges. In Entrepreneurship, Finance, Governance and Ethics (Vol. 3, pp. 113-135). Springer 
Netherlands.

Manawaduge, A. S. (2012). Corporate governance practices and their impacts on corporate performance in an emerging market: the case of Sri Lanka. (Doctor of Philosophy), University of Wollongong. Retrieved from http://ro.uow.edu.au/theses/3676/

Marra, A., \& Mazzola, P. (2014). Is Corporate Board More Effective Under IFRS or “It's Just an Illusion”?. Journal of Accounting, Auditing \& Finance, 29(1), 31-60.

Meangbua, O., Dhakal, S., \& Kuwornu, J. K. (2019). Factors influencing energy requirements and CO2 emissions of households in Thailand: A panel data analysis. Energy Policy, 129, 521-531.

Moudud-Ul-Huq, S. (2015). Corporate governance practices in Bangladesh: A comparative analysis between conventional banks and Islamic banks. International Journal of Management and Business Research, 5(1), 53-60.

Nekhili, M., Amar, I. F. B., Chtioui, T., \& Lakhal, F. (2016). Free cash flow and earnings management: The moderating role of governance and ownership. Journal of Applied Business Research, 32(1), 255.

Nijam, H. M., \& Athambawa, J. (2016). IFRS Adoption and Financial Reporting Quality: A Review of Evidences in Different Jurisdictions. International Letters of Social and Humanistic Sciences, 69, 93-106. https://doi.org/10.18052/www.scipress.com/ILSHS.69.93

Nouri, Y., \& Abaoub, E. (2014). Accounting Manipulations and IFRS: Evidence from French Companies. International Journal of Economics and Finance, 6(11), 229.

Pallant, J. (2011). Survival manual. A step by step guide to data analysis using SPSS.

Rahman, M. M., Al Bashir, M. M., Choudhury, T. T., \& Rabby, S. M. (2014). Disclosure of Corporate Governance in Banking Sector of Bangladesh. European Journal of Business and Management, 6(6), 17-37. Retrieved from iiste.org/Journals/index.php/EJBM/article/download/11122/11423

Ramsey, J. B. (1969). Tests for specification errors in classical linear least-squares regression analysis. Journal of the Royal Statistical Society: Series B (Methodological), 31(2), 350-371.

Rouf, M. (2011). The Financial Performance (Profitability) and Corporate Governance Disclosure in the Annual Reports of Listed Companies of Bangladesh. Journal of Economics and Business Research, 17(2), 103-117.

Roychowdhury, S. (2006). Earnings management through real activities manipulation. Journal of Accounting and Economics, 42(3), 335-370.

Salleh, M. F. B. M. (2009). Political influence, corporate governance and financial reporting quality: evidence from companies in Malaysia (Doctor of Philosophy), Massey University, Wellington, New Zealand. Retrieved from http://mro.massey.ac.nz/handle/10179/3633

Sathye, M., Islam, J., \& Hu, H. (2014). Examining the Relationship of Corporate Governance and Bank Performance: Evidence from Bangladesh. Australasian Accounting, Business and Finance Journal, 8(3), 55-70.

Scott, W. R. (2014). Financial accounting theory (7 ed.). Pearson Education Canada.

Shawn, H., Jung, J.-G., \& Do, S.-h. (2015). Relation between Corporate Governance and Earnings Management, and the Role of IFRS: Evidence from Korea. Bulletin of Japanese Association for International Accounting Studies, 2014(1), 139-150.

Surifah, S. (2017). The Role of Corporate Governance in the Effect Earnings Management Has on Firm Value. Journal of Indonesian Economy and Business, 31(1), 51-69.

Wahyuni, E. T., Puspitasari, G., \& Puspitasari, E. (2020). Has IFRS improved Accounting Quality in Indonesia? A Systematic Literature Review of 2010-2016. Journal of Accounting and Investment, 1(1), 19-44.

Wahyuningrum, I. F. S., \& Rizqi, D. M. a. (2019). The Effect of IFRS Convergence toward Earnings Management with Managerial Ownership as a Moderating Variable. Jurnal Dinamika Akuntansi, 11(2), 160-169.

Wong, R., \& Wong, H. (2014). Examine the impact on companies for external reporting in Hong Kong with the adoption of International Financial Reporting Standards (IFRS). Oxford Journal: An International Journal of Business \& Economics, 9(2), 204-210.

World Bank Press Release. (July 01, 2015). WB Update Says 10 Countries Move Up in Income Bracket. Retrieved $\begin{array}{llll}\text { February 27, 2017, from } & \text { 27 }\end{array}$ http://www.worldbank.org/en/news/press-release/2015/07/01/new-world-bank-update-shows-bangladesh-kenya 
-myanmar-and-tajikistan-as-middle-income-while-south-sudan-falls-back-to-low-income

Yasser, Q. R., Mamun, A. A., Chapple, E., \& Chapple, E. (2016). The Relationship between Board Leadership Structure and Earnings Management in Asia-Pacific. Accounting Research Journal, 29(4), 413-428. https://doi.org/10.1108/ARJ-06-2015-0080

Yie Ke, F. (2020). The level of conservatism and earnings management during IFRS adoption. Jurnal Keuangan dan Perbankan, 24(1), 53-67.

Yoon, S. S., Kim, H. J., \& Woodruff, G. (2012). On the models and estimation of discretionary accruals. Retrieved from http://ifas.xmu.edu.cn/uploads/soft/121226/\%E8\%AE\%BA\%E6\%96\%87.pdf

Yoon, S. S., Miller, G., \& Jiraporn, P. (2006). Earnings management vehicles for Korean firms. Journal of International Financial Management \& Accounting, 17(2), 85-109.

Zang, A. Y. (2011). Evidence on the trade-off between real activities manipulation and accrual-based earnings management. The Accounting Review, 87(2), 675-703.

Appendix 1.Corporate governance provisions for CG Index

\begin{tabular}{|c|c|c|c|}
\hline CG Attributes & $\begin{array}{l}\text { Sl. } \\
\text { No. }\end{array}$ & Corporate Governance Provisions of CGI & $\begin{array}{l}\text { Compliance } \quad(1) \\
\text { Non-compliance }(0)\end{array}$ \\
\hline \multirow{11}{*}{$\begin{array}{l}\text { Board } \\
\text { characteristics }\end{array}$} & 1 & Board size (shall not be $<5 \&>20$ ) & \\
\hline & 2 & $\begin{array}{l}\text { Independent Directors } \\
\text { (at least } 1 / 5 \text { th or } 20 \% \text { of total number of directors in the } \\
\text { board) }\end{array}$ & \\
\hline & 3 & $\begin{array}{l}\text { Appointment of Independent non shareholder director } \\
\text { (does not hold any share) }\end{array}$ & \\
\hline & 4 & $\begin{array}{l}\text { Qualification of Independent directors } \\
\text { (at least one should be professional) }\end{array}$ & \\
\hline & 5 & $\begin{array}{l}\text { Independent director should not be connected to } \\
\text { company's Sponsor Or Director Or Shareholder who } \\
\text { holds }>1 \%\end{array}$ & \\
\hline & 6 & $\begin{array}{l}\text { Independent director is not the shareholder, director or } \\
\text { officers of any member of Stock Exchange or } \\
\text { Intermediary of the cap. market. }\end{array}$ & \\
\hline & 7 & $\begin{array}{l}\text { Independent directors is not the independent director in } \\
\text { more than } 3 \text { (three) listed companies }\end{array}$ & \\
\hline & 8 & $\begin{array}{l}\text { The post of independent directors cannot remain vacant } \\
\text { for more than } 90 \text { days }\end{array}$ & \\
\hline & 9 & $\begin{array}{l}\text { The Board shall lay down a Code of Conduct of all } \\
\text { Board Members and need to be recorded. }\end{array}$ & \\
\hline & 10 & $\begin{array}{l}\text { The tenure of office of an Independent Director shall be } \\
\text { for a period of } 3 \text { (three) years }\end{array}$ & \\
\hline & 11 & $\begin{array}{l}\text { Chairman and CEO are separate } \\
\text { (No CEO duality) }\end{array}$ & \\
\hline \multirow{9}{*}{$\begin{array}{l}\text { Directors report } \\
\text { to shareholders }\end{array}$} & 12 & $\begin{array}{l}\text { Industry outlook and possible future developments in the } \\
\text { industry. }\end{array}$ & \\
\hline & 13 & Declare fairness of the financial statements & \\
\hline & 14 & Consistent application of Accounting policies & \\
\hline & 15 & Compliance with IAS/IFRS (BAS/BFRS) & \\
\hline & 16 & Provide assurance for going concern assumption & \\
\hline & 17 & Address the risk and concerns of the company & \\
\hline & 18 & Provide information of related party transactions & \\
\hline & 19 & Key operating information (at least 5 yrs.) & \\
\hline & 20 & Explanation for significant deviation in performance & \\
\hline
\end{tabular}




\begin{tabular}{|c|c|c|}
\hline & & $\begin{array}{l}\text { (compare to last year or in between interim \& annual } \\
\text { report) }\end{array}$ \\
\hline & 21 & Number of Board meetings per year - at least 4 \\
\hline & 22 & No. of meetings attend by directorzat least $50 \%$ \\
\hline & 23 & Information about Directors shareholding \\
\hline & 24 & Details about Ownership Structure \\
\hline & 25 & $\begin{array}{llll}\begin{array}{l}\text { Information about directors } \\
\text { reappointment }\end{array} & \text { appointment } & \text { or } \\
\end{array}$ \\
\hline & 26 & $\begin{array}{l}\text { Information about remuneration of directors including } \\
\text { independent directors }\end{array}$ \\
\hline & 27 & $\begin{array}{l}\text { Provide assurance about effective internal control system } \\
\text { and monitoring }\end{array}$ \\
\hline & 28 & Declaration of dividend \\
\hline & 29 & $\begin{array}{l}\text { Policy for appointment of CEO, CFO, HoIA \& CS (have } \\
\text { no duality in the role) }\end{array}$ \\
\hline $\begin{array}{l}\text { Executive } \\
\text { Manaoement }\end{array}$ & 30 & Clearly define their role and responsibilities \\
\hline & 31 & $\begin{array}{l}\text { Attendance of CFO \& CS } \\
\text { (shall be present in all board meeting) }\end{array}$ \\
\hline & 32 & Existence of audit committee \\
\hline & 33 & Audit committee size (at least 3 members) \\
\hline & 34 & Independent directors in audit committee \\
\hline & 35 & $\begin{array}{l}\text { Chairman of audit committee shall be an Independent } \\
\text { director }\end{array}$ \\
\hline $\begin{array}{l}\text { Audit } \\
\text { Committee }\end{array}$ & 36 & $\begin{array}{l}\text { Audit committee members qualification } \\
\text { (Chairman should be professional accountant and all of } \\
\text { them are financially literate) }\end{array}$ \\
\hline & 37 & $\begin{array}{l}\text { No meeting without Independent directors } \\
\text { (at least one should be present) }\end{array}$ \\
\hline & 38 & Role of audit committee is clearly defined \\
\hline & 39 & $\begin{array}{l}\text { Chairman of the audit committee shall remain present in } \\
\text { AGM }\end{array}$ \\
\hline & 40 & Reporting to board of directors and shareholders \\
\hline & 41 & Appointment of Big4 affiliated audit firms \\
\hline External Auditor & 42 & $\begin{array}{l}\text { Should not engage in advisory or internal audit services } \\
\text { and does not hold any share of firm }\end{array}$ \\
\hline & 43 & Details policy about auditor's rotation \\
\hline & 44 & $\begin{array}{l}\text { Assurance of top management (CEO \& CFO) regarding } \\
\text { financial statements }\end{array}$ \\
\hline $\begin{array}{l}\text { Reporting and } \\
\text { Compliance }\end{array}$ & 45 & $\begin{array}{l}\text { Published audited annual reports on time as specified by } \\
\text { SEC (within } 120 \text { days from the end of company's fiscal } \\
\text { year) }\end{array}$ \\
\hline & 46 & $\begin{array}{l}\text { Compliance certificate of Corporate Governance } \\
\text { Guidelines from auditor }\end{array}$ \\
\hline & 47 & Offer Interim Financial Reporting (Quarterly) \\
\hline & 48 & Board has more than $20 \%$ independent director \\
\hline $\begin{array}{l}\text { Progressive } \\
\text { Practice }\end{array}$ & 49 & The company has own code of ethics \\
\hline & 50 & Have Institutional shareholders \\
\hline
\end{tabular}

